\title{
EDITORIAL
}

\section{Onderzoek en opinie}

\section{Peter F. A. Mulders ${ }^{1}$}

Published online: 25 May 2018

(c) The Author(s) 2018

In dit zomernummer van ons tijdschrift vinden jullie een diversiteit aan artikelen; van onderzoeksstukken tot meer opinieachtige verhalen. Wel dusdanig dat er een peer-review proces aan vooraf gegaan is. Meestal worden de artikelen beter als het constructief commentaar van de reviewers geïmplementeerd is. Allereerst een bijdrage van Waltman en Van Roermund uit Maastricht over uitademingslucht bij het opsporen van prostaatkanker, een voorbeeld dat kanker niet alleen via de bloedbaan maar ook via urine of in dit geval uitademingslucht opgespoord kan worden. Wordt zeker nog vervolgd. Peter Rosier zet ons weer op scherp ten aanzien van het urodynamisch onderzoek. Waarna Van
Soest en collega's de enorme veranderingen ten aanzien van de hormonale behandelingen bij prostaatkanker bespreken. Dus niets te veel gezegd ten aanzien van deze variatie. Veel leesplezier en een goede zomer.

Open Access This article is distributed under the terms of the Creative Commons Attribution 4.0 International License (http:// creativecommons.org/licenses/by/4.0/), which permits unrestricted use, distribution, and reproduction in any medium, provided you give appropriate credit to the original author(s) and the source, provide a link to the Creative Commons license, and indicate if changes were made.

Prof. dr. Peter F.A. Mulders uroloog

Prof. dr. Peter F. A. Mulders

peter.mulders@radboudumc.nl

1 afdeling Urologie, Radboudumc, Nijmegen, Nederland 